\title{
Pengaruh Pupuk Majemuk NPK + Zn terhadap Pertumbuhan, Produksi dan Serapan Zn Padi Sawah di Vertisol, Sragen
}

\author{
DOI 10.18196/pt.2016.059.75-83
}

\author{
Imas Masithoh Devangsari*, Azwar Maas, Benito Heru Purwanto \\ Jurusan Ilmu Tanah, Fakultas Pertanian, Universitas Gadjah Mada, \\ Jl. Flora, Bulaksumur, Depok, Sleman, Yogyakarta 55281, Indonesia, Telp./fax.: (0274) 563062, \\ e-mail:dimasmasithoh@yahoo.com
}

\begin{abstract}
ABSTRAK
Vertisol merupakan tanah yang memiliki pH netral- agak alkalis. Ketersediaan Zn menurun dengan naiknya pH. Timbulnya gejala kekahatan hara mikro khususnya Zn, juga disebabkan penggunaan bibit unggul berdaya hasil tinggi disertai pemupukan tidak seimbang. Di samping itu, serapan Zn oleh tanaman merupakan proses berkelanjutan yang mengakibatkan penurunan kadar hara Zn di daerah perakaran. Penelitian ini bertujuan untuk mengetahui efektivitas pupuk majemuk NPK plus Zn terhadap serapan hara, pertumbuhan dan produksi tanaman padi. Percobaan disusun menggunakan rancangan acak kelompok lengkap (completely randomized block design) dengan sepuluh perlakuan dan diulang sebanyak tiga kali. Dosis pupuk majemuk NPK yang diberikan adalah 300kg/ha. Hasil penelitian menunjukkan bahwa pupuk majemuk NPK +Zn tidak memberikan pengaruh terhadap tinggi tanaman, jumlah anakan dan berat tanaman. Tidak terlihat peningkatan hasil disebabkan oleh pemberian tambahan Zn sampai takaran 2 \% dari pupuk majemuk NPK +Zn yang diberikan. Ada kecenderungan perlakuan NPK +0,75 \% Zn memberikan hasil yang tertinggi. Aplikasi pupuk majemuk NPK +Zn secara nyata meningkatkan serapan Zn. Kata kunci: pH, produksi, pupuk, Vertisol, Zn
\end{abstract}

\begin{abstract}
Vertisol is a soil that has neutral to slightly alkaline pH. Zinc availability decreases with increasing pH. The existence of symptoms micronutrients scarcity, especially zinc, also caused by the use of highly yielding seeds with unbalanced fertilization. In addition, Zn uptake by plants is sustainability process which resulted in a decrease in nutrient levels of $Z n$ in the root zone. The aim of the research was to determine the optimum Zn formula that can be added to the NPK compound fertilizer and to determine the effectiveness of the fertilizer on the growth and yield of rice. The experiment was arranged by completely randomized block design with 10 treatments and 3 replicates of each treatment. NPK compound fertilizer dose was given 300kg / ha. The result of this study showed that the compound fertilizer NPK + Zn had no effect on plant height, number of tillers and weight of the plant. The additional dose compound of 2\% Zn to the dose of compound fertilizer NPK + Zn did not increase the yield. There was a tendency NPK treatment $+0.75 \%$ Zn deliver the highest results. NPK compound fertilizer application + Zn significantly increased the uptake of Zn.

Keywords: pH, production, fertilizers, Vertisol, Zn
\end{abstract}

\section{PENDAHULUAN}

Kebutuhan manusia akan pangan yang semakin lama semakin meningkat seiring dengan bertambahnya jumlah penduduk dunia sekitar $1,38 \%$ per tahun mengharuskan adanya peningkatan pangan dari hasil budidaya tanaman yang dilakukan. Di Indonesia padi masih merupakan salah satu sumber makanan pokok utama masyarakat. Padi termasuk dalam suku padi-padian atau poaceae. Secara ringkas, bercocok tanam padi mencakup persemaian, pemindahan atau penanaman, pemeliharaan (termasuk pengairan, penyiangan, perlindungan tanaman, serta pemupukan), dan panen. Tanah sawah baik untuk pertumbuhan tanaman padi yang memiliki kandungan fraksi pasir, debu dan klei dalam perbandingan tertentu. Curah hujan yang baik rata-rata $200 \mathrm{~mm}$ per bulan atau lebih, dengan distribusi selama 4 bulan, curah hujan yang dikehendaki per tahun sekitar 1500-2000 mm (Alam, 2006).

Vertisol merupakan tanah dengan $\mathrm{pH}$ nertalagak alkalis. Kekahatan Zn terjadi pada tanah alkali ber-pH tinggi, tanah berkapur, dan kapasitas tukar kation rendah (Sims, 1986). Vertisol merupakan tanah yang didominasi mineral klei tipe 2:1 (Deckers, 2001). Ion-ion seng, mangan dan besi dijumpai sebagai bagian integral dari 
lempung silikat, terutama tipe 2:1. Faktor-faktor yang juga mempercepat berkurangnya unsur mikro dalam tanah adalah peningkatan hasil panen, kehilangan unsur mikro karena pencucian, pengapuran, dan meningkatnya kemurnian pupuk buatan (Friensen et al., 1980). Akibatnya produksi tanaman menjadi menurun seiring dengan waktu. Timbulnya gejala kekahatan hara mikro khususnya Zn, disebabkan karena penggunaan bibit unggul berdaya hasil tinggi disertai pemupukan berat. Di samping itu, serapan Zn oleh tanaman merupakan proses berkelanjutan yang mengakibatkan penurunan kadar hara Zn di daerah perakaran (Dang et al., 1994).

Pemupukan unsur hara mikro seperti Zn pada budidaya tanaman padi saat ini hampir tidak pernah dilakukan, beberapa gejala kekurangan $\mathrm{Zn}$ diantaranya daun tanaman padi hilang ketegarannya dan cenderung mengapung di atas air; setengah dari trubus bagian bawah, daunnya berwarna hijau pucat 2-4 hari setelah digenangi; kemudian khlorotik dan mulai mengering setelah 3-7 hari digenangi. Gejala khlorosis yang terberat umumnya terjadi pada saat air menggenang dalam.

Penanganan terhadap tanaman padi yang mengalami defisiensi $\mathrm{Zn}$ ini yaitu dengan pemupukan. Jika gejala kekurangan $\mathrm{Zn}$ ringan, cukup diberikan $5 \mathrm{~kg} \mathrm{Zn/ha}\left(\mathrm{ZnSO}_{4}\right)$ dan bila gejalanya berat diberikan $20 \mathrm{~kg} \mathrm{Zn/ha}\left(\mathrm{ZnSO}_{4}\right)$. Berdasarkan data IRRI, tanaman padi menyerap unsur hara $\mathrm{Zn}$ sebesar 0,05 kg/ha per ton hasil gabah, atau sekitar $0,35 \mathrm{~kg} /$ ha pada tingkat produktivitas gabah sebesar 7 ton GKP/ha (Dang, 1994). Berdasarkan penelitian Khan et al. (2007), dari uji coba 4 dosis $\mathrm{ZnSO}_{4}$ yakni 0, 5, 10 dan 15 $\mathrm{kg} /$ ha pada tanaman padi, dosis $10 \mathrm{~kg} \mathrm{ZnSO}_{4}$ menghasilkan hasil GKP tertinggi dibandingkan perlakuan lainnya.

Tujuan penelitian ini adalah untuk mengeta- hui efektivitas pupuk majemuk NPK plus Zn terhadap serapan hara, pertumbuhan dan produksi tanaman padi.

\section{BAHAN DAN METODE}

Bahan yang digunakan dalam penelitian ini adalah varietas padi Situbagendit, pupuk organik buatan dengan dosis $500 \mathrm{~kg} / \mathrm{ha}$, Urea $200 \mathrm{~kg} /$ ha, dan majemuk NPK plus Zn 300 kg/ha. Sifat kimia Vertisol disajikan pada Tabel 1.

Penelitian dilaksanakan dengan menggunakan Rancangan Acak Kelompok Lengkap, dengan 10 (sepuluh) perlakuan yaitu tanpa pupuk, majemuk NPK + $0 \% \mathrm{Zn}$, majemuk NPK + 0,25 $\% \mathrm{Zn}$, majemuk NPK + 0,5 \% Zn, majemuk $\mathrm{NPK}+0,75 \% \mathrm{Zn}$, majemuk NPK + $1 \% \mathrm{Zn}$, majemuk NPK + 1,25\% Zn, majemuk NPK + $1,5 \% \mathrm{Zn}$, majemuk NPK $+1,75 \% \mathrm{Zn}$, majemuk $\mathrm{NPK}+2 \%$ Zn dengan ulangan sebanyak 3 (tiga) kali. Petakan yang digunakan berukuran $8 \mathrm{~m} \mathrm{x}$ $5 \mathrm{~m}$ per perlakuan dengan sistem Jajar Legowo. Aplikasi pemupukan dilakukan dalam beberapa tahap dengan pupuk yang sama setiap petakan kecuali tanpa pupuk tidak diberikan penambahan pupuk:

- Petroganik (500 kg/ha) : sebelum tanam

- Pupuk Urea (200 kg/ha): 1/2 dosis (7 hari setelah tanam), 1/4 dosis (21 hari setelah tanam), dan $1 / 4$ dosis (35 hari setelah tanam)

- Pupuk majemuk NPK(300 kg/ha) : 1/2 dosis (7 hari setelah tanam), dan $1 / 2$ dosis (21 hari setelah tanam)

Variabel Pengamatan meliputi Pengamatan agronomi, Pengamatan Hasil, pengujian sampel tanah dan Jaringan Tanaman. Pengamatan agronomi dilakukan terhadap 3 tanaman setiap petak perlakuan pada saat tanaman padi berumur 21 hari setelah tanam, 35 hari setelah tanam dan 45 hari setelah tanam. Pengamatan yang 
dilakukan meliputi tinggi tanaman dan jumlah anakan tanaman padi sawah. Pengamatan hasil menggunakan metode penimbangan Gabah kering panen per petak $(\mathrm{kg})$ kemudian dikonversi dalam bentuk ton/hektar. Sebelum perlakuan dilakukan pengambilan sampel tanah untuk analisis tanah sebelum dan setelah perlakuan, dengan cara mengambil sampel tanah secara acak dengan kedalaman 0-20 cm kemudian dikompositkan. Sampel tanaman diperoleh dari 3 tanaman per petak dengan cara mencabut tanaman pada saat panen. Setelah itu dipisahkan antara bagian trubus dan akar. Analisis kimia tanah meliputi: $\mathrm{pH}\left(\mathrm{H}_{2} \mathrm{O}\right)$ dan $\mathrm{pH}(\mathrm{KCl})$ dengan $\mathrm{pH}$ meter, C-Organik dengan metode Walkey and Black, N-total dengan metode Kjedahl, KPK dengan amonium asetat netral, $\mathrm{P}$ tersedia metode Olsen, $\mathrm{K}$ tersedia dengan ekstrak ammonium asetat $\mathrm{pH} 7, \mathrm{Zn}$ tersedia dengan DTPA (Balittan, 2009). Kadar unsur $\mathrm{Zn}$ dalam tanaman (trubus) dianalisis dengan metode destruksi basah (Balittan, 2009) kemudian dihitung serapan masingmasing unsur hara dengan rumus serapan hara sebagai berikut:

- Serapan Hara = BK (bobot kering) x \% konsentrasi hara pada jaringan tanaman

Tabel 1. Sifat Kimia Vertisol

\begin{tabular}{lccc}
\hline \multicolumn{1}{c}{ Jenis Analisis } & Satuan & Nilai & Harkat* \\
\hline pH H2O & - & 6,83 & Netral \\
C-organik & $\%(\mathrm{~b} / \mathrm{b})$ & 3,33 & Tinggi \\
Bahan organik & $\%(\mathrm{~b} / \mathrm{b})$ & 5,74 & \\
N-total & $\%(\mathrm{~b} / \mathrm{b})$ & 0,19 & Rendah \\
P205tersedia & $\mathrm{mg} / \mathrm{kg}$ & 6,53 & Rendah \\
K tersedia & $\mathrm{mg} / \mathrm{kg}$ & 97,5 & Rendah \\
Zn tersedia & $\mathrm{mg} / \mathrm{kg}$ & 0,08 & Rendah \\
Kapasitas Pertukaran Kation & $\mathrm{cmol}(+) / \mathrm{kg}$ & 32 & Tinggi \\
Nisbah C/N & - & 17,53 & Tinggi \\
\hline
\end{tabular}

* Harkat disesuaikan dengan Balai Penelitian Tanah (2009), b/b: berat per berat

Data hasil percobaan dianalisis dengan analisis sidik ragam (Analysis of variance) untuk menge- tahui adanya perlakuan yang berpengaruh beda nyata. Apabila pengaruhnya nyata (F hitung $>\mathrm{F}$ tabel) dengan jenjang nyata $5 \%>$ maka dilanjutkan dengan Uji Duncan untuk mengetahui perlakuan mana yang berbeda nyata.

\section{HASIL DAN PEMBAHASAN}

Pengaruh Pupuk Majemuk NPK +Zn terhadap Pertumbuhan Padi Sawah

Hasil pengamatan untuk mengetahui tinggi tanaman pada saat 21 hari setelah tanam, 35 hari setelah tanam, 49 hari setelah tanam dan 93 hari setelah tanam (hst) dari pengaruh pemberian perlakuan disajikan pada Tabel 2. Tabel 2 menunjukkan bahwa terjadi peningkatan tinggi tanaman pada 21 hst, 35 hst dan 49 hst. Hal tersebut dikarenakan pertumbuhan padi berada fase vegetatif maksimum. Pada fase ini terdapat dua tahapan penting yaitu pembentukan anakan aktif kemudian disusul dengan perpanjangan batang.

Tabel 2. Pengaruh Pupuk NPK +Zn terhadap Tinggi Tanaman Padi Sawah di Vertisol

\begin{tabular}{|c|c|c|c|c|}
\hline \multirow{2}{*}{ Perlakuan } & \multicolumn{4}{|c|}{ Tinggi Tanaman $(\mathrm{cm})$} \\
\hline & 21 hst & 35 hst & 49 hst & 93 hst \\
\hline Tanpa pupuk & $47,69 \mathrm{~b}$ & $59,26 \mathrm{~b}$ & $68,91 \mathrm{~b}$ & $85,48 b$ \\
\hline Majemuk NPK 300 kg/ha & $50,54 a b$ & $71,96 a$ & $83,33 \mathrm{a}$ & $99,34 \mathrm{a}$ \\
\hline Majemuk NPK 300 kg/ha $+0,25 \%$ Zn & $51,57 a b$ & $69,37 a$ & 79,97 a & $94,59 \mathrm{a}$ \\
\hline Majemuk NPK $300 \mathrm{~kg} / \mathrm{ha}+0,50 \% \mathrm{Zn}$ & $51,99 a b$ & $72,00 \mathrm{a}$ & $81,30 a$ & $99,10 \mathrm{a}$ \\
\hline Majemuk NPK $300 \mathrm{~kg} / \mathrm{ha}+0,75 \% \mathrm{Zn}$ & $53,02 \mathrm{a}$ & $72,50 \mathrm{a}$ & 83,27 a & $99,19 \mathrm{a}$ \\
\hline Majemuk NPK 300 kg/ha $+1 \%$ Zn & $52,93 \mathrm{a}$ & 71,14 a & $82,12 \mathrm{a}$ & $98,77 \mathrm{a}$ \\
\hline Majemuk NPK 300 kg/ha $+1,25 \%$ Zn & $53,91 \mathrm{a}$ & $73,39 a$ & 83,70 a & $99,33 \mathrm{a}$ \\
\hline Majemuk NPK 300 kg/ha $+1,50 \%$ Zn & $49,92 a b$ & $68,43 a$ & 80,70 a & $98,36 \mathrm{a}$ \\
\hline Majemuk NPK 300 kg/ha $+1,75 \%$ Zn & $49,42 a b$ & $69,07 a$ & $78,64 \mathrm{a}$ & $94,54 \mathrm{a}$ \\
\hline Majemuk NPK 300 kg/ha + $2 \%$ Zn & $50,43 a b$ & $72,37 a$ & $81,53 \mathrm{a}$ & $97,86 \mathrm{a}$ \\
\hline \multicolumn{5}{|c|}{$\begin{array}{l}\text { Keterangan: Angka yang diikuti oleh huruf yang sama menunjukkan hasil tidak berbeda } \\
\text { nyata antar perlakuan dengan DMRT taraf } a=5 \% \text {. }\end{array}$} \\
\hline \multicolumn{5}{|c|}{ Tinggi tanaman padi pada saat panen yaitu } \\
\hline \multicolumn{5}{|c|}{ saat umur tanaman padi 93 hari setelah tanam } \\
\hline \multicolumn{5}{|c|}{ menunjukkan perbedaan yang signifikan. Pada } \\
\hline \multicolumn{5}{|c|}{ perlakuan majemuk NPK 300kg per ha + $0 \%$} \\
\hline
\end{tabular}


Zn pemberian dosis tersebut memberikan nilai tertinggi yaitu 99,34 cm dengan peningkatan tinggi tanaman sebesar 13,86 cm dibandingkan tanpa perlakuan $(85,48 \mathrm{~cm})$ tetapi tidak berbeda nyata dengan perlakuan majemuk NPK 300 kg/ ha + berbagai dosis $\mathrm{Zn}$. Tinggi tanaman yang sama pada setiap perlakuan ini diduga karena kebutuhan hara pada masa pertumbuhan vegetatif sama-sama telah terpenuhi, peningkatan dosis Zn tidak begitu mempengaruhi pertumbuhan tinggi tanaman. Hasil pengamatan untuk mengetahui pengaruh perlakuan terhadap jumlah anakan tanaman padi disajikan pada Tabel 3 .

Tabel 3. Pengaruh Pupuk NPK + Zn terhadap Jumlah Anakan Tanaman Padi Sawah di Vertisol

\begin{tabular}{lcccc}
\hline \multirow{2}{*}{ Perlakuan } & \multicolumn{4}{c}{ Jumlah Anakan } \\
\cline { 2 - 5 } & 21 hst & 35 hst & 49 hst & 93 hst \\
\hline Tanpa pupuk & $14 \mathrm{c}$ & $21 \mathrm{c}$ & $21 \mathrm{~b}$ & $16 \mathrm{a}$ \\
Majemuk NPK $300 \mathrm{~kg} / \mathrm{ha}$ & $18 \mathrm{ab}$ & $27 \mathrm{ab}$ & $26 \mathrm{ab}$ & $19 \mathrm{a}$ \\
Majemuk NPK $300 \mathrm{~kg} / \mathrm{ha}+0,25 \%$ Zn & $16 \mathrm{abc}$ & $25 \mathrm{abc}$ & $25 \mathrm{ab}$ & $17 \mathrm{a}$ \\
Majemuk NPK $300 \mathrm{~kg} / \mathrm{ha}+0,50 \%$ Zn & $19 \mathrm{a}$ & $26 \mathrm{ab}$ & $24 \mathrm{ab}$ & $17 \mathrm{a}$ \\
Majemuk NPK $300 \mathrm{~kg} / \mathrm{ha}+0,75 \%$ Zn & $17 \mathrm{abc}$ & $25 \mathrm{bc}$ & $23 \mathrm{ab}$ & $16 \mathrm{a}$ \\
Majemuk NPK $300 \mathrm{~kg} / \mathrm{ha}+1 \% \mathrm{Zn}$ & $17 \mathrm{abc}$ & $30 \mathrm{a}$ & $28 \mathrm{a}$ & $20 \mathrm{a}$ \\
Majemuk NPK $300 \mathrm{~kg} / \mathrm{ha}+1,25 \%$ Zn & $17 \mathrm{abc}$ & $26 \mathrm{abc}$ & $26 \mathrm{ab}$ & $18 \mathrm{a}$ \\
Majemuk NPK $300 \mathrm{~kg} / \mathrm{ha}+1,50 \%$ Zn & $15 \mathrm{bc}$ & $26 \mathrm{ab}$ & $25 \mathrm{ab}$ & $17 \mathrm{a}$ \\
Majemuk NPK $300 \mathrm{~kg} / \mathrm{ha}+1,75 \% \mathrm{Zn}$ & $18 \mathrm{abc}$ & $27 \mathrm{ab}$ & $27 \mathrm{a}$ & $17 \mathrm{a}$ \\
Majemuk NPK $300 \mathrm{~kg} / \mathrm{ha}+2 \% \mathrm{Zn}$ & $19 \mathrm{a}$ & $27 \mathrm{ab}$ & $24 \mathrm{ab}$ & $16 \mathrm{a}$ \\
\hline
\end{tabular}

Keterangan: Angka yang diikuti oleh huruf yang sama menunjukkan hasil tidak berbeda nyata antar perlakuan dengan DMRT taraf á=5\%.

Tabel 3 menunjukkan terjadinya peningkatan jumlah anakan tanaman padi pada semua perlakuan pada saat 21 hari setelah tanam dan 35 hari setelah tanam karena pada saat fase vegetatif tanaman padi tumbuh dengan baik. Sementara pada saat 49 hari setelah tanam mengalami penurunan karena memasuki fase bunting (reproduksi) dan anakan yang tidak produktif akan mati. Pada fase reproduksi dari 35 hari setelah tanam sampai 65 hari setelah tanam ini hara yang tersedia lebih dimanfaatkan untuk proses pembungaan yang dimulai dengan pembentukan malai. Malai terus berkembang sampai keluar seutuhnya dari pelepah daun dan serbuk sari menonjol keluar dari bulir dan terjadi proses pembuahan.

Hasil uji sidik ragam dengan tingkat signifikasi $5 \%$ pada berbagai perlakuan terhadap jumlah anakan produktif tanaman padi pada saat panen (pada saat umur 93 hari setelah tanam) menunjukkan tidak ada beda nyata. Pada perlakuan NPK $300 \mathrm{~kg} / \mathrm{ha}+1 \%$ Zn tanaman padi memiliki jumlah anakan produktif paling tinggi yaitu sebesar 20 malai sedangkan pada perlakuan tanpa pupuk dan majemuk NPK $300 \mathrm{~kg} /$ ha $+2 \%$ Zn memiliki jumlah anakan produktif yang paling rendah yaitu sebesar 16 malai. Hal tersebut terjadi karena tidak ada penambahan unsur hara yang diberikan ke tanah. Soepardi et al., (1985) mengemukakan bahwa pemberian hara mikro seperti $\mathrm{Zn}$ tidak selalu memberikan hasil yang nyata terhadap pertumbuhan tanaman, meskipun tanah tersebut berkadar hara Zn rendah. Hasil penelitian pada tanah-tanah di Jawa menunjukkan bahwa meskipun kadar Zn tersedia berada di bawah batas kritikal kahat yaitu $0,7 \mathrm{ppm}$, tetapi tanaman padi tetap tidak memberikan respons terhadap pemupukan $\mathrm{Zn}$, namun secara umum adanya pemberian 5 hingga $10 \mathrm{~kg} \mathrm{Zn} / \mathrm{ha}$ menghasilkan komponen produksi yang terberat.

Pengaruh Pupuk Majemuk NPK +Zn terhadap Biomassa Tanaman Padi

Hasil pengamatan untuk mengetahui bobot segar dan bobot kering trubus dari pengaruh pemberian perlakuan disajikan pada Tabel 4. Bobot kering tanaman merupakan parameter yang digunakan untuk menggambarkan besarnya fotosintesis tanaman. Semakin besar bobot kering tanaman maka semakin besar pula fotosintesis tanaman, sehingga semakin besar pula 
kualitas tanaman. Tolok ukur pertumbuhan tanaman yang paling baik adalah bobot kering karena bobot kering merupakan gambaran akumulasi asimilat yang merupakan perwujudan dari aktivitas pertumbuhan tanaman (Salisbury \& Ross, 1995).

Tabel 4. Pengaruh Pupuk Majemuk NPK + Zn terhadap Bobot Segar dan Bobot Kering Trubus Tanaman Padi Sawah di Vertisol

\begin{tabular}{lcc}
\hline \multicolumn{1}{c}{ Perlakuan } & $\begin{array}{c}\text { Bobot Segar Trubus } \\
(\mathrm{g})\end{array}$ & $\begin{array}{c}\text { Bobot Kering Trubus } \\
(\mathrm{g})\end{array}$ \\
\hline Tanpa pupuk & $50,99 \mathrm{a}$ & $40,15 \mathrm{~b}$ \\
Majemuk NPK $300 \mathrm{~kg} / \mathrm{ha}$ & $66,46 \mathrm{a}$ & $52,56 \mathrm{ab}$ \\
Majemuk NPK $300 \mathrm{~kg} / \mathrm{ha}+$ 0,25\% Zn & $70,30 \mathrm{a}$ & $51,79 \mathrm{ab}$ \\
Majemuk NPK $300 \mathrm{~kg} / \mathrm{ha}+$ 0,50\% Zn & $63,08 \mathrm{a}$ & $49,80 \mathrm{ab}$ \\
Majemuk NPK $300 \mathrm{~kg} / \mathrm{ha}+0,75 \% \mathrm{Zn}$ & $62,93 \mathrm{a}$ & $51,52 \mathrm{ab}$ \\
Majemuk NPK $300 \mathrm{~kg} / \mathrm{ha}+1 \% \mathrm{Zn}$ & $74,31 \mathrm{a}$ & $54,92 \mathrm{a}$ \\
Majemuk NPK $300 \mathrm{~kg} / \mathrm{ha}+1,25 \% \mathrm{Zn}$ & $67,18 \mathrm{a}$ & $53,66 \mathrm{a}$ \\
Majemuk NPK $300 \mathrm{~kg} / \mathrm{ha}+1,50 \% \mathrm{Zn}$ & $66,53 \mathrm{a}$ & $50,52 \mathrm{ab}$ \\
Majemuk NPK $300 \mathrm{~kg} / \mathrm{ha}+1,75 \% \mathrm{Zn}$ & $72,69 \mathrm{a}$ & $52,06 \mathrm{ab}$ \\
Majemuk NPK $300 \mathrm{~kg} / \mathrm{ha}+2 \% \mathrm{Zn}$ & $61,33 \mathrm{a}$ & $48,69 \mathrm{ab}$ \\
\hline
\end{tabular}

Keterangan: Angka yang diikuti oleh huruf yang sama menunjukkan hasil tidak berbeda nyata antar perlakuan dengan DMRT taraf á =5\%.

Berdasarkan hasil uji sidik ragam dengan tingkat signifikasi $5 \%$ pada berbagai perlakuan terhadap bobot segar trubus tidak menunjukkan adanya beda nyata tetapi pada bobot kering trubus menunjukkan adanya beda nyata antar perlakuan. Bobot kering (BK) trubus dan bobot segar (BS) trubus pada perlakuan dengan dosis NPK $300 \mathrm{~kg} \mathrm{ha}^{-1}+1 \%$ Zn menunjukkan hasil tertinggi yaitu sebesar 74,31 gram dan bobot segar sebesar 54,92 gram.

Pengaruh Pupuk Majemuk NPK + Zn terhadap N total, P, K dan Zn Tersedia Tanah

Hasil analisis tanah untuk mengetahui pengaruh perlakuan terhadap kadar hara tersedia dalam tanah disajikan pada Tabel 5. Hasil uji sidik ragam dengan tingkat signifikasi $5 \%$ pada berbagai perlakuan terhadap Nitrogen total di dalam tanah menunjukkan ada beda nyata antar perlakuan. Kadar $\mathrm{N}$ total tanah tertinggi pada perlakuan dosis NPK $300 \mathrm{~kg} \mathrm{ha}^{-1}+0,25 \%$ Zn dan $1 \%$ Zn yaitu sebesar 0,26\% dan kadar $\mathrm{N}$ total terendah pada perlakuan tanpa pupuk yaitu sebesar $0,20 \%$. Tingginya nilai $\mathrm{pH}$ pada perlakuan (tabel 1) menyebabkan nitrat terlindi sehingga ammonium lebih tersedia karena bersifat lebih stabil. Hal tersebut yang menyebabkan tingginya $\mathrm{N}$ total pada perlakuan $1 \% \mathrm{Zn}$ dan pemberian bahan organik ke lahan akan meningkatkan kadar $\mathrm{N}$ total tanah. Menurut Balittan (2009) kadar $\mathrm{N}$ total dalam tanah tersebut tergolong sedang. $\mathrm{N}$ di dalam tanah maupun di dalam tanaman bersifat sangat mobile, sehingga keberadaan $\mathrm{N}$ di dalam tanah cepat berubah atau bahkan hilang.

Tabel 5. Pengaruh Pupuk Majemuk NPK $+Z n$ terhadap $\mathrm{N}$ total, $\mathrm{P}, \mathrm{K}$ dan Zn Tersedia Tanah

\begin{tabular}{lcccc}
\hline \multicolumn{1}{c}{ Perlakuan } & $\begin{array}{c}\mathrm{N} \text { total } \\
(\%)\end{array}$ & $\begin{array}{c}\mathrm{P}_{2} \mathrm{O}_{5} \\
\text { Tersedia } \\
(\mathrm{mg} / \mathrm{kg})\end{array}$ & $\begin{array}{c}\mathrm{K} \\
\text { Tersedia } \\
(\mathrm{me} \%)\end{array}$ & $\begin{array}{c}\text { Zn Tersedia } \\
(\mathrm{mg} / \mathrm{kg})\end{array}$ \\
\hline Tanpa pupuk & $0,20 \mathrm{~d}$ & $7,02 \mathrm{a}$ & $0,15 \mathrm{~b}$ & $0,10 \mathrm{c}$ \\
Majemuk NPK $300 \mathrm{~kg} / \mathrm{ha}$ & $0,23 \mathrm{c}$ & $6,01 \mathrm{a}$ & $0,16 \mathrm{ab}$ & $0,12 \mathrm{bc}$ \\
Majemuk NPK $300 \mathrm{~kg} / \mathrm{ha}+0,25 \%$ Zn & $0,26 \mathrm{a}$ & $7,29 \mathrm{a}$ & $0,22 \mathrm{a}$ & $0,13 \mathrm{bc}$ \\
Majemuk NPK $300 \mathrm{~kg} / \mathrm{ha}+0,50 \% \mathrm{Zn}$ & $0,23 \mathrm{c}$ & $6,86 \mathrm{a}$ & $0,18 \mathrm{ab}$ & $0,14 \mathrm{bc}$ \\
Majemuk NPK $300 \mathrm{~kg} / \mathrm{ha}+0,75 \%$ Zn & $0,22 \mathrm{c}$ & $6,90 \mathrm{a}$ & $0,16 \mathrm{ab}$ & $0,12 \mathrm{bc}$ \\
Majemuk NPK $300 \mathrm{~kg} / \mathrm{ha}+1 \% \mathrm{Zn}$ & $0,26 \mathrm{a}$ & $8,92 \mathrm{a}$ & $0,19 \mathrm{ab}$ & $0,19 \mathrm{bc}$ \\
Majemuk NPK $300 \mathrm{~kg} / \mathrm{ha}+1,25 \%$ Zn & $0,24 \mathrm{~b}$ & $7,97 \mathrm{a}$ & $0,17 \mathrm{ab}$ & $0,17 \mathrm{bc}$ \\
Majemuk NPK $300 \mathrm{~kg} / \mathrm{ha}+1,50 \%$ Zn & $0,23 \mathrm{c}$ & $7,23 \mathrm{a}$ & $0,14 \mathrm{~b}$ & $0,21 \mathrm{~b}$ \\
Majemuk NPK $300 \mathrm{~kg} / \mathrm{ha}+1,75 \%$ Zn & $0,23 \mathrm{c}$ & $8,58 \mathrm{a}$ & $0,15 \mathrm{ab}$ & $0,22 \mathrm{~b}$ \\
Majemuk NPK $300 \mathrm{~kg} / \mathrm{ha}+2 \%$ Zn & $0,25 \mathrm{~b}$ & $7,00 \mathrm{a}$ & $0,19 \mathrm{ab}$ & $0,34 \mathrm{a}$ \\
\hline Keterangan: Angka yang diikuti oleh huruf yang sama menunjukkan hasil tidak berbeda \\
nyata antar perlakuan dengan DMRT taraf á=5\%.
\end{tabular}

Kadar $\mathrm{P}$ tersedia tanah tertinggi pada perlakuan dosis NPK $300 \mathrm{~kg} \mathrm{ha}^{-1}+1 \% \mathrm{Zn}$ yaitu sebesar $8,92 \mathrm{mg} / \mathrm{kg}$ dan kadar P tersedia terendah pada perlakuan dosis NPK $300 \mathrm{~kg} \mathrm{ha}^{-1}+0$ $\%$ Zn yaitu sebesar $6,01 \mathrm{mg} / \mathrm{kg}$. Hasil uji sidik ragam dengan tingkat signifikasi $5 \%$ pada perlakuan dosis pupuk menunjukkan bahwa tidak ada beda nyata terhadap $\mathrm{P}$ tersedia tanah setelah perlakuan. Menurut Balittan (2009) kadar P 
tersedia dalam tanah tergolong sangat rendah. Rendahnya unsur P tersebut dikarenakan $\mathrm{pH}$ tanah pada semua perlakuan tergolong agak alkalis sehingga unsur $\mathrm{P}$ diikat oleh ion $\mathrm{Ca}$ (basa).

Kadar $\mathrm{K}$ tersedia tanah tertinggi pada perlakuan dosis NPK $300 \mathrm{~kg} \mathrm{ha}^{-1}+0,25 \% \mathrm{Zn}$ yaitu sebesar 0,22 me \% dan kadar $\mathrm{K}$ tersedia terendah pada perlakuan dosis NPK $300 \mathrm{~kg} \mathrm{ha}^{-1}+1,5$ $\%$ Zn yaitu sebesar 0,14 me \%. Menurut Balittan (2009) kadar K tersedia dalam tanah termasuk kriteria rendah. Rendahnya unsur hara K dikarenakan $\mathrm{K}$ terjerap pada kisi mineral lempung sehingga Kalium menjadi kurang tersedia. Berdasarkan hasil uji sidik ragam dengan tingkat signifikasi $5 \%$ pada berbagai perlakuan terhadap K tesedia di dalam tanah menunjukkan ada beda nyata antar perlakuan, tetapi nilai kadar $\mathrm{K}$ tersedia pada setiap perlakuan tidak berbeda jauh. Hal tersebut dikarenakan pemberian dosis pupuk NPK yang sama pada setiap perlakuan yaitu sebesar $300 \mathrm{~kg} / \mathrm{ha}$.

Berdasarkan hasil uji sidik ragam dengan tingkat signifikasi $5 \%$ pada berbagai perlakuan terhadap kadar Zn tersedia dalam tanah setelah panen menunjukkan ada beda nyata antar perlakuan. Kadar hara Zn pada perlakuan meningkat seiring dengan meningkatnya penambahan $\mathrm{Zn}$ dengan kadar $\mathrm{Zn}$ tersedia tanah tertinggi pada perlakuan dosis majemuk NPK $300 \mathrm{~kg} \mathrm{ha}^{-1}$ + $2 \% \mathrm{Zn}$ yaitu sebesar $0,34 \mathrm{mg} / \mathrm{kg}$ dan kadar Zn tersedia terendah pada perlakuan tanpa pupuk yaitu sebesar 0,10 mg/kg. Kadar hara Zn dalam tanah tersebut tergolong defisiensi menurut Balittan (2009) karena sudah diserap oleh tanaman. Menurut Seatz dan Jurinak (1957) dalam Suryanto (1991) pada kisaran pH 5,5-7,0 ketersediaan Zn menurun. Kelarutan ini meningkat dengan makin rendahnya $\mathrm{pH}$ dan menurun dengan makin tingginya $\mathrm{pH}$. Sims dan Patrick (1978) dalam Suryanto (1991) melaporkan bahwa kenaikan $\mathrm{pH}$ dari 6,0 menjadi 7,5 dapat menurunkan kandungan Zn sebanyak 39 \%. Contoh reaksi yang menerangkan hubungan penurunan kelarutan unsur hara mikro (kation) dengan peningkatan $\mathrm{pH}$ tanah adalah sebagai berikut:

$$
\begin{gathered}
\mathrm{Zn}^{2+}+2 \mathrm{OH} \\
\text { Larut }
\end{gathered} \longrightarrow \begin{gathered}
\mathrm{Zn}(\mathrm{OH})_{2} \\
\text { tidak larut }
\end{gathered}
$$

Jika $\mathrm{pH}$ naik, bentuk ion dari kation hara mikro yang semula mudah larut diubah menjadi hidroksida atau oksida yang tidak larut sehingga tidak dapat diserap oleh tanaman.

\section{Pengaruh Pupuk Majemuk NPK +Zn terhadap Kadar dan Serapan Hara dalam Padi Sawah}

Hasil analisis tanah untuk mengetahui pengaruh perlakuan terhadap konsentrasi hara dalam trubus dan serapan disajikan pada Tabel 6 .

Tabel 5. Pengaruh Pupuk Majemuk NPK $+Z n$ terhadap

\begin{tabular}{|c|c|c|c|c|c|c|}
\hline \multirow[b]{2}{*}{ Perlakuan } & \multicolumn{2}{|c|}{ N } & \multicolumn{2}{|c|}{$P$} & \multicolumn{2}{|c|}{ K } \\
\hline & $\begin{array}{l}\text { Trubus } \\
(\%)\end{array}$ & $\begin{array}{l}\text { Serapan } \\
\text { (gr/tan) }\end{array}$ & $\begin{array}{c}\text { Trubus } \\
(\%)\end{array}$ & $\begin{array}{l}\text { Serapan } \\
\text { (gr/tan) }\end{array}$ & $\begin{array}{c}\text { Trubus } \\
(\%)\end{array}$ & $\begin{array}{r}\text { Serapan } \\
\text { (gr/tan) }\end{array}$ \\
\hline Tanpa pupuk & $0,42 c$ & $0,17 \mathrm{~b}$ & $0,10 \mathrm{f}$ & $0,04 \mathrm{c}$ & $0,60 \mathrm{e}$ & $0,24 c$ \\
\hline $\begin{array}{l}\text { Majemuk NPK } 300 \\
\mathrm{~kg} / \mathrm{ha}\end{array}$ & $0,49 \mathrm{~b}$ & $0,26 a$ & $0,14 \mathrm{c}$ & $0,08 \mathrm{ab}$ & $0,74 \mathrm{~b}$ & $0,39 a b$ \\
\hline $\begin{array}{l}\text { Majemuk NPK } 300 \\
\mathrm{~kg} / \mathrm{ha}+0,25 \% \text { Zn }\end{array}$ & $0,50 \mathrm{~b}$ & $0,26 a$ & $0,12 d$ & $0,06 \mathrm{ab}$ & $0,66 \mathrm{~d}$ & $0,34 \mathrm{~b}$ \\
\hline $\begin{array}{l}\text { Majemuk NPK } 300 \\
\mathrm{~kg} / \mathrm{ha}+0,50 \% \text { Zn }\end{array}$ & $0,56 \mathrm{a}$ & $0,28 a$ & $0,11 \mathrm{e}$ & $0,06 \mathrm{bc}$ & $0,72 \mathrm{~b}$ & $0,35 \mathrm{~b}$ \\
\hline $\begin{array}{l}\text { Majemuk NPK } 300 \\
\mathrm{~kg} / \mathrm{ha}+0,75 \% \mathrm{Zn}\end{array}$ & $0,59 a$ & $0,30 a$ & $0,16 a$ & $0,08 \mathrm{a}$ & $0,90 \mathrm{a}$ & $0,46 \mathrm{a}$ \\
\hline $\begin{array}{l}\text { Majemuk NPK } 300 \\
\mathrm{~kg} / \mathrm{ha}+1 \% \mathrm{Zn}\end{array}$ & $0,57 a$ & $0,31 \mathrm{a}$ & $0,14 \mathrm{c}$ & $0,08 a b$ & $0,68 c$ & $0,37 \mathrm{~b}$ \\
\hline $\begin{array}{l}\text { Majemuk NPK } 300 \\
\mathrm{~kg} / \mathrm{ha}+1,25 \% \text { Zn }\end{array}$ & $0,58 a$ & $0,31 \mathrm{a}$ & $0,14 \mathrm{c}$ & $0,07 a b$ & $0,74 \mathrm{~b}$ & $0,40 a b$ \\
\hline $\begin{array}{l}\text { Majemuk NPK } 300 \\
\mathrm{~kg} / \mathrm{ha}+1,50 \% \text { Zn }\end{array}$ & $0,58 \mathrm{a}$ & $0,30 a$ & $0,15 \mathrm{~b}$ & $0,08 a b$ & $0,74 \mathrm{~b}$ & $0,37 \mathrm{~b}$ \\
\hline $\begin{array}{l}\text { Majemuk NPK } 300 \\
\mathrm{~kg} / \mathrm{ha}+1,75 \% \text { Zn }\end{array}$ & $0,58 a$ & $0,30 a$ & $0,14 \mathrm{c}$ & $0,07 a b$ & $0,72 \mathrm{~b}$ & $0,37 \mathrm{~b}$ \\
\hline $\begin{array}{l}\text { Majemuk NPK } 300 \\
\mathrm{~kg} / \mathrm{ha}+2 \% \mathrm{Zn}\end{array}$ & $0,57 a$ & $0,28 a$ & $0,15 b$ & $0,07 a b$ & $0,74 \mathrm{~b}$ & $0,36 \mathrm{~b}$ \\
\hline
\end{tabular}
$\mathrm{N}$ total, $\mathrm{P}, \mathrm{K}$ dan Zn Tersedia Tanah

Hasil percobaan menunjukkan bahwa kadar hara $\mathrm{N}$ dalam daun berbeda nyata dari semua perlakuan penambahan pupuk $\mathrm{N}$ dengan dosis $200 \mathrm{~kg}$ Urea/ha dan NPK $300 \mathrm{~kg} / \mathrm{ha}$. Perlakuan 
kadar 0,75 \% Zn memiliki kadar $\mathrm{N}$ tanaman paling tinggi yaitu sebesar 0,59\% dan terendah pada perlakuan tanpa pupuk yaitu sebesar 0,42 $\%$. Kadar angka kecukupan $\mathrm{N}$ untuk padi saat panen bagian trubus menurut Doberman dan Fairhust (2000) adalah 0,6-0,8\%. Sementara berdasarkan hasil yang diperoleh kadar $\mathrm{N}$ padi berada pada kisaran angka kecukupan tersebut. Hal tersebut dapat disebabkan jumlah $\mathrm{N}$ tanah selama proses budidaya yang tersedia bagi tanaman.

Serapan $\mathrm{N}$ trubus menunjukkan adanya beda nyata antar perlakuan yang diberikan. Perlakuan tanpa pupuk menunjukkan beda nyata dengan semua perlakuan dosis pupuk plus Zn. Perlakuan yang memberikan serapan $\mathrm{N}$ tertinggi pada perlakuan dosis $1 \%$ Zn dan 1,25 \% Zn sebesar 0,31 $\mathrm{g} /$ tanaman dan yang terendah pada perlakuan tanpa pupuk sebesar 0,17 g/tanaman. Perbedaan kadar nitrogen trubus dapat disebabkan karena $\mathrm{N}$ tanah pada kondisi yang berbeda pula. Kondisi ketersediaan nitrogen di dalam tanah menentukan jumlah nitrogen yang dapat diserap oleh tanaman. Banyaknya nitrogen yang diserap tanaman dipengaruhi oleh bobot kering tanaman dan kadar $\mathrm{N}$ dalam jaringan.

Hasil uji sidik ragam dengan tingkat signifikasi $5 \%$ pada berbagai perlakuan terhadap kadar P trubus menunjukkan adanya beda nyata antar perlakuan. Kadar hara P dalam daun yang tidak dipupuk (perlakuan tanpa pupuk) memiliki kandungan hara $\mathrm{P}$ terendah yaitu sebesar 0,10 $\%$, sedangkan pada perlakuan dosis NPK 300 $\mathrm{kg} /$ ha memiliki kandungan P trubus sebesar 0,14 $\%$ Sementara pada perlakuan dosis NPK 300 $\mathrm{kg} / \mathrm{ha}+0,75 \%$ Zn memiliki kandungan hara P trubus yang paling tinggi yaitu sebesar 0,16\%. Kadar angka kecukupan $\mathrm{P}$ untuk padi saat panen bagian trubus menurut Doberman dan Fairhust (2000) adalah 0,1-0,15\%. Sementara berdasarkan hasil yang diperoleh kadar $\mathrm{P}$ trubus padi pada semua perlakuan berada pada kisaran angka kecukupan tersebut. Hal tersebut dapat disebabkan ketersediaan P selama proses budidaya yang berada pada kondisi cukup tersedia dari pupuk yang diberikan.

Serapan P trubus menunjukkan adanya beda nyata antar perlakuan yang diberikan. Perlakuan tanpa pupuk menunjukkan tidak beda nyata dengan perlakuan dosis NPK + 0,50 \% Zn. Perlakuan dosis NPK $+0,75 \%$ Zn memberikan serapan $\mathrm{P}$ trubus tertinggi yaitu sebesar $0,08 \mathrm{~g} /$ tanaman dan serapan terendah pada perlakuan tanpa pupuk yaitu sebesar 0,04 g/tanaman. Perbedaan kadar P trubus juga dapat disebabkan faktor lingkungan selain kondisi hara.

Hasil uji sidik ragam dengan tingkat signifikasi $5 \%$ pada berbagai perlakuan terhadap kadar Kalium trubus menunjukkan ada beda nyata. Perlakuan tanpa pupuk memiliki kadar Kalium trubus terendah yaitu sebesar 0,60\% sedangkan pada perlakuan dosis pupuk Urea $200 \mathrm{~kg} /$ ha dan NPK + 0,75\% Zn memiliki kandungan tertinggi yaitu sebesar 0,90 \%. Persentase angka kecukupan $\mathrm{K}$ untuk padi saat panen bagian trubus menurut Doberman dan Fairhust (2000) adalah $1,5-2 \%$. Sementara berdasarkan hasil yang diperoleh kadar K padi pada semua perlakuan belum mencapai angka kecukupan tersebut. Hal tersebut dapat disebabkan karena bahan organik tanah yang tidak dapat diubah menjadi $\mathrm{K}$ tersedia.

Serapan K trubus menunjukkan adanya beda nyata antar perlakuan yang diberikan. Perlakuan yang memberikan serapan $\mathrm{K}$ trubus tertinggi pada perlakuan dosis NPK $300 \mathrm{~kg} / \mathrm{ha}+0,75$ $\% \mathrm{Zn}$ sebesar 0,46 g/tanaman dan yang terendah pada perlakuan tanpa pupuk sebesar 0,24 $\mathrm{g} /$ tanaman. Kondisi ketersediaan $\mathrm{K}$ di dalam tanah menentukan jumlah $\mathrm{K}$ yang dapat diserap 
oleh tanaman. Hal ini disebabkan unsur K yang terserap ke dalam trubus mampu meningkatkan bobot trubus sehingga unsur $\mathrm{K}$ yang terserap dalam trubus pun tinggi. Hasil analisis tanaman untuk mengetahui pengaruh perlakuan terhadap kadar hara dan serapan $\mathrm{Zn}$ disajikan pada Tabel 7 .

Tabel 7. Pengaruh Dosis Pemupukan NPK $+Z n$ terhadap Konsentrasi dan Serapan Zn Trubus Tanaman Padi Sawah di Vertisol

\begin{tabular}{lcc}
\hline \multicolumn{1}{c}{ Perlakuan } & $\begin{array}{c}\text { Konsentrasi Zn trubus } \\
(\mathrm{mg} / \mathrm{kg})\end{array}$ & $\begin{array}{c}\text { Serapan Zn } \\
(\mathrm{mg} / \text { tanaman })\end{array}$ \\
\hline Tanpa pupuk & $28,35 \mathrm{c}$ & $1,14 \mathrm{c}$ \\
Majemuk NPK $300 \mathrm{~kg} / \mathrm{ha}$ & $35,30 \mathrm{bc}$ & $1,86 \mathrm{bc}$ \\
Majemuk NPK $300 \mathrm{~kg} / \mathrm{ha}+0,25 \% \mathrm{Zn}$ & $36,03 \mathrm{bc}$ & $1,95 \mathrm{abc}$ \\
Majemuk NPK $300 \mathrm{~kg} / \mathrm{ha}+0,50 \% \mathrm{Zn}$ & $36,25 \mathrm{bc}$ & $1,79 \mathrm{bc}$ \\
Majemuk NPK $300 \mathrm{~kg} / \mathrm{ha}+0,75 \% \mathrm{Zn}$ & $42,61 \mathrm{abc}$ & $2,20 \mathrm{abc}$ \\
Majemuk NPK $300 \mathrm{~kg} / \mathrm{ha}+1 \% \mathrm{Zn}$ & $38,70 \mathrm{bc}$ & $2,15 \mathrm{abc}$ \\
Majemuk NPK $300 \mathrm{~kg} / \mathrm{ha}+1,25 \% \mathrm{Zn}$ & $58,25 \mathrm{ab}$ & $3,05 \mathrm{ab}$ \\
Majemuk NPK $300 \mathrm{~kg} / \mathrm{ha}+1,50 \% \mathrm{Zn}$ & $61,07 \mathrm{ab}$ & $3,14 \mathrm{ab}$ \\
Majemuk NPK $300 \mathrm{~kg} / \mathrm{ha}+1,75 \% \mathrm{Zn}$ & $55,54 \mathrm{ab}$ & $2,89 \mathrm{ab}$ \\
Majemuk NPK $300 \mathrm{~kg} / \mathrm{ha}+2 \% \mathrm{Zn}$ & $67,55 \mathrm{a}$ & $3,28 \mathrm{a}$ \\
\hline
\end{tabular}

Keterangan: Angka yang diikuti oleh huruf yang sama menunjukkan hasil tidak berbeda nyata antar perlakuan dengan DMRT taraf á $=5 \%$.

Hasil uji sidik ragam dengan tingkat signifikasi $5 \%$ percobaan pada berbagai perlakuan dosis pupuk majemuk NPK + Zn terhadap unsur hara mikro $\mathrm{Zn}$ di dalam jaringan tanaman padi menunjukkan ada beda nyata. Perlakuan tanpa pupuk memiliki kadar Zn trubus terendah yaitu sebesar 28,35 mg/kg sedangkan pada perlakuan dosis pupuk Urea $200 \mathrm{~kg} / \mathrm{ha}$ dan majemuk NPK+ $2 \% \mathrm{Zn}$ memiliki kandungan tertinggi yaitu sebesar 67,55 mg/kg. Pada percobaan terdapat kecenderungan peningkatan kadar hara Zn dari konsentrasi $0 \% \mathrm{Zn}$ seiring dengan adanya peningkatan pemberian $\mathrm{Zn}$ hingga $2 \%$. Hal ini dikarenakan terjadinya peningkatan serapan $\mathrm{Zn}$ dari pupuk, sehingga mendukung peningkatan bobot kering total tanaman dibandingkan pada tanaman padi tanpa pupuk. Welch, House and
Alloway (1974); Welch, 1986 dalam Rengel (1999) mengemukakan, mobilitas Zn di dalam tanaman sangat tergantung pada kecukupan ketersediaan Zn dari media pertumbuhan. Kecukupan $\mathrm{Zn}$ pada media pertumbuhan akan diserap dan diangkut keluar dari jaringan vegetatif ke dalam jaringan reproduktif dan biji.

Titik kritis toksik pada daun tanaman adalah $<100$ ig/g bobot kering (Ruano et al., 1988 dalam Marschner, 1995). menurut Mengel dan Kirkby (1987) dalam Roesmarkam dan Yuwono (2002), kadar Zn dalam tanaman berkisar antara 20 ppm - 70 ppm. Hasil analisis kadar Zn trubus dalam penelitian berada pada kisaran tersebut. Serapan Zn trubus menunjukkan adanya beda nyata antar perlakuan yang diberikan. Perlakuan yang memberikan serapan Zn trubus tertinggi pada perlakuan dosis majemuk NPK $300 \mathrm{~kg} / \mathrm{ha}+2 \%$ Zn sebesar 3,28 mg/tanaman dan yang terendah pada perlakuan tanpa pupuk sebesar 1,14 mg/ tanaman.

Pengaruh Pupuk Majemuk NPK +Zn terhadap Produksi Padi Sawah

Hasil pengamatan untuk mengetahui pengaruh perlakuan terhadap produksi padi (gabah kering panen) disajikan pada Tabel 8.

Tabel 8. Pengaruh Dosis Pemupukan NPK $+Z n$ terhadap Produksi Padi Sawah di Vertisol

\begin{tabular}{lc}
\multicolumn{1}{c}{ Perlakuan } & Gabah Kering Panen (kg/ha) \\
\hline Tanpa pupuk & $6,13 \mathrm{~b}$ \\
Majemuk NPK $300 \mathrm{~kg} / \mathrm{ha}$ & $9,04 \mathrm{a}$ \\
Majemuk NPK $300 \mathrm{~kg} / \mathrm{ha}+0,25 \%$ Zn & $8,74 \mathrm{a}$ \\
Majemuk NPK $300 \mathrm{~kg} / \mathrm{ha}+0,50 \%$ Zn & $8,83 \mathrm{a}$ \\
Majemuk NPK $300 \mathrm{~kg} / \mathrm{ha}+0,75 \%$ Zn & $9,42 \mathrm{a}$ \\
Majemuk NPK $300 \mathrm{~kg} / \mathrm{ha}+1 \%$ Zn & $9,23 \mathrm{a}$ \\
Majemuk NPK $300 \mathrm{~kg} / \mathrm{ha}+1,25 \%$ Zn & $9,13 \mathrm{a}$ \\
Majemuk NPK $300 \mathrm{~kg} / \mathrm{ha}+1,50 \%$ Zn & $8,54 \mathrm{a}$ \\
Majemuk NPK $300 \mathrm{~kg} / \mathrm{ha}+1,75 \%$ Zn & $8,48 \mathrm{a}$ \\
Majemuk NPK $300 \mathrm{~kg} / \mathrm{ha}+2 \%$ Zn & $9,08 \mathrm{a}$ \\
\hline
\end{tabular}

Keterangan: Angka yang diikuti oleh huruf yang sama menunjukkan hasil tidak berbeda nyata antar perlakuan dengan DMRT taraf $a ́=5 \%$. 
Kegiatan pemanenan sebaiknya dilakukan saat tanaman padi telah menguning $90 \%$. Pada penelitian ini pemanenan dilakukan pada saat tanaman berumur 93 hst. Hasil uji sidik ragam dengan tingkat signifikasi $5 \%$ pada berbagai perlakuan dosis pemupukan terhadap produksi tanaman padi menunjukkan ada beda nyata antar perlakuan dengan produksi tertinggi sebesar 9,42 ton/ha pada perlakuan dosis majemuk NPK $300 \mathrm{~kg} / \mathrm{ha}+$ 0,75 \% Zn. Penggunaan dosis $300 \mathrm{~kg} / \mathrm{ha}$ majemuk NPK ditambah $200 \mathrm{~kg}$ Urea/ha mampu meningkatkan produksi tanaman padi sebesar 47,47 \% jika dibandingkan dengan tanpa pupuk, sedangkan penggunaan dosis $300 \mathrm{~kg} /$ ha majemuk NPK + 0,75\% Zn ditambah dengan $200 \mathrm{~kg}$ Urea/ ha mampu meningkatkan produksi tanaman padi sebesar 53,67\% dibandingkan dengan tanpa pupuk.

Swietlik (1996) mengemukakan bahwa aplikasi Zn sebesar $30 \mathrm{~g} /$ tanaman pada tanaman, tidak memberikan pengaruh nyata terhadap pertumbuhan tanaman dan hasil bila kandungan $\mathrm{Zn}$ daun tidak di bawah 20\% dari nilai kritikal. Hasil senada juga diperoleh pada penelitian Singh et al, (1986), Neilsen et al, (1987), dan Liang et al, (1992), di mana penambahan pupuk Zn pada tanaman kacang hijau dan tanaman alfalfa tidak menimbulkan respons yang nyata, namun terdapat peningkatan bobot kering tanaman dibanding dengan perlakuan tanpa $\mathrm{Zn}$. Hal ini mengindikasikan bahwa adanya peningkatan pemberian $\mathrm{Zn}$ akan meningkatkan serapan $\mathrm{Zn}$ tanaman yang secara tidak langsung mengakibatkan peningkatan bobot kering total tanaman.

\section{SIMPULAN}

1. Pemberian pupuk majemuk NPK $+Z n$ tidak memberikan pengaruh yang nyata terhadap tinggi tanaman, jumlah anakan, bobot kering akar, dan bobot kering tajuk.
2. Tidak terdapat beda nyata dan peningkatan produksi padi sawah sampai takaran $2 \% \mathrm{Zn}$ pada pupuk majemuk NPK yang ditambahkan, tetapi ada kecenderungan takaran 0,75 $\%$ Zn memberikan produksi (gabah kering panen) tertinggi yaitu sebesar 9,4 ton/hektar.

3. Pemberian pupuk majemuk NPK + Zn secara nyata meningkatkan serapan $\mathrm{Zn}$ tajuk tanaman.

\section{DAFTAR PUSTAKA}

Alam, M. 2006 Produksi Tanaman Padi dan Efisiensi Pemupukan Nitrogen pada Lahan Sawah Bekas Pertanaman Kedelai. Jurnal Agrivigor 6: 26-31

Balai Penelitian Tanah. 2009. Petunjuk Teknis Analisis Kimia Tanah, Tanaman, Air, dan Pupuk, Balai Penelitian Tanah, Badan Penelitian dan Pengembangan Pertanian. Bogor

Dang, YP., R.C. Dalal, D.G.Edward and K.G. Tiller. 1994. Kinetics of Zinc Desorption from Vertisols. Soil Sci. Amer. J. 58:13921399

Deckers, J., O. Spaargaren and F. Nachtergaele. 2001. Vertisols: Genesis, properties and soilscape management for sustainable development. p. 3-20. In Syers, J. K. F., W. T. Penning De Vries and P. Nyamudeza (Eds): The Sustainable Management of Vertisols. IBSRAM Proceeding No. 20

Dobermann, A. and T. Fairhust. 2000. Rice, Nutrient Disorders and Nutrient Management. IRRI and Potash and Phosphate Institute of Canada. Philipines

Friensen, D.K., A.S.R. Juo, and M.H. Miller. 1980. Liming and Lime-phosphorus-zinc Interaction in Two Nigerian Ultisols:l, Interactions in the Soil. Soil Sci. Soc. Amer. J. 44:1221-1226. Mengel, $K$ and E.A. Kirkby. 1982. Principles of Plant Nutrition 3rd edition International Potash Institute. Warblaufen-Bern Switzerland

Rosmarkam, A. dan N.W. Yuwono. 2002. IImu Kesuburan Tanah. Kanisius. Yogyakarta

Salisbury, F.B. and C.W.Ross. 1992. Plant Physiology. Wadsworth Publishing Company. Belmont. California. 681 pp.Sims, J.T. 1986. Soil pH Effects on the Distribution and Plant Availability of Manganese, Copper and Zinc. Soil Sci. Amer. J. 50:367-373

Singh, J.P. R.E. Karamanos and J.W.B. Stewart. 1986. PhosphorusInduce Zinc Deficiency in Wheat on Residual Phosphorus Plots. Agron. J. 68:668-675

Swietlik, D. 1996. Responses of Citrus Trees in Texas to Foliar and Soil Zn Applications. Proc. Int. Soc. Citriculture. p. 772776

Welch, R.M. 2007. Micronutrients, Agriculture and Nutrition: Linkage for Improve Health and Well Being. http:// www,css,cornell,edu/foodsystems/ micros \&agriman. 